\title{
Exhausted Tea Leaves - a low cost bioadsorbent for the removal of Lead (II) and Zinc (II) ions from their aqueous solution
}

\author{
Bindra Shrestha*, P.L. Homagai, M.R. Pokhrel, K.N. Ghimire \\ Central Department of Chemistry, Tribhuvan University, Kirtipur, Kathmandu, Nepal. \\ E-mail binraghu@yahoo.com
}

\begin{abstract}
An efficient and cost effective bioadsorbent has been prepared from exhausted tea leaves using hydrazine monohydrate. The aminated tea leaves (ATL) was characterised by elemental and spectral analysis. The batch adsorption study was performed using ATL for the removal of $\mathrm{Pb}^{++}$and $\mathrm{Zn}^{++}$from their aqueous solution. Adsorption experiment was conducted as the function of solution $\mathrm{pH}$, initial metal concentration and contact time. The maximum adsorption capacity of the adsorbent was found to be $120.8 \mathrm{mg} / \mathrm{g}$ for $\mathrm{Pb}^{++}$and $79.76 \mathrm{mg} / \mathrm{g}$ for $\mathrm{Zn}^{++}$. These results indicated that the aminated tea leaves hold great potential to remove $\mathrm{Pb}^{++}$and $\mathrm{Zn}^{++}$from aqueous solution.
\end{abstract}

Key words: Tea Leaves, bioadsorbent, heavy metals, Langmuir-isotherm, amination

\section{Introduction}

Most of the heavy metals are toxic and present a threat to human health and the environment ${ }^{1}$. To remove these metal ions from their aqueous solution at trace concentration, adsorption has been used as an effective method than other conventional methods ${ }^{2,3}$. Recently many researchers are focused on the use of waste materials as adsorbent for removal of heavy metals from industrial waste water, as they are eco-friendly, cost effective and more efficient. Chitosan, chitin, sugarcane bagasse, apple and orange juice residue, wheat straw, rice husk, tea waste have been investigated as biosorbent for removal of heavy metals ${ }^{4-10}$.

Metal binding capacity of biosorbents is due to the functional groups such as hydroxyl, carboxylate, sulphate, amine, amide, phosphate groups present in the biosorbent. The density of these groups which are effective for metal binding is generally low in most of the biosorbents. Surface modification of such biosorbents increases such groups and significantly enhances the sorption capacity. In particular the amino group onto an adsorbent has been found to be one of the most promising chelating groups for the adsorption of the heavy metal ions from their aqueous solution ${ }^{11}$.

In this study, waste tea leaves are selected as biosorbent which vitally contains lignin, cellulose and hemicelluloses ${ }^{12}$. These natural polymers have been reported having low metal binding capacity. To enhance the metal binding capacity, the biosorbent is chemically modified to introduce amino group on the surface of the biosorbent. This aminated biosorbent is used to remove common metallic pollutants like lead and zinc.

\section{*Corresponding author}




\section{Materials and Experimental}

\section{Chemicals}

The stock solutions of $1000 \mathrm{mg} / \mathrm{L}$ of $\mathrm{Pb}^{++}$and $\mathrm{Zn}^{++}$were prepared by dissolving required amount of lead nitrate and zinc sulphate in $0.1 \mathrm{M} \mathrm{HNO}_{3}$. The stock solutions were diluted to required dilution of working solutions. In all the experimental works $0.1 \mathrm{M}$ solution of 2-[4-(2-hydroxymethyl)-1piperazinyl] ethanesulfonic acid [HEPES] was used as buffer. The $\mathrm{pH}$ of the working solutions was maintained using $0.1 \mathrm{M} \mathrm{HNO}_{3}$ and $0.1 \mathrm{M} \mathrm{NaOH}$ solution. All the chemicals used were of AR grade and double distilled water was used for the experiment. During the experiment the concentration of metal ions were analyzed using Atomic Absorption Spectroscopy [Chemito AA 202, AAS].

\section{Biosorbent preparation}

$50 \mathrm{~g}$ of exhausted tea leaves was washed with boiling water till the filtrate became colorless. It was dried in an oven. The dried adsorbent was powdered and sieved through $212 \mu$ sieve. The adsorbent was charred with concentrated $\mathrm{H}_{2} \mathrm{SO}_{4}$. After charring the sample was washed thoroughly with distilled water to remove free acid and then dried in an oven. The adsorbent was chemically modified by using hydrazine monohydrate. The prepared adsorbent is aminated tea leaves [ATL].

\section{Experimental}

The biosorption of $\mathrm{Pb}^{++}$and $\mathrm{Zn}^{++}$onto ATL was investigated by batch equilibrium experiments. To study the effect of initial concentration on adsorption, $20 \mathrm{ml}$ of metal solution with different concentration were mixed with $25 \mathrm{mg}$ of the adsorbent and shaken for $24 \mathrm{hrs}$. at $150 \mathrm{rpm}$ at $25^{0} \mathrm{C}$ in a mechanical shaker. A series of adsorption experiment were carried at 1 to 6 initial $\mathrm{pH}$ to study the effect of $\mathrm{pH}$. The kinetics of the adsorption was studied by shaking $25 \mathrm{mg}$ adsorbent with $20 \mathrm{ml}$ metal solution for 5 to 240 min. After adsorption the solutions were filtered and analyzed for the concentration of metal ions.

The adsorption efficiency A\% can be calculated by using equation (1)

$$
A \%=\frac{C_{i}-C_{e}}{C_{i}} \times 100
$$

The amount of metal adsorbed is the concentration of metal ions on the adsorbent and can be calculated on the basis of mass balance principle as given in equation 2 .

$$
q=\frac{\mathrm{C}_{i}-\mathrm{C}_{\mathrm{e}}}{\mathrm{W}} \times \frac{\mathrm{L}}{1000}
$$

where $\mathrm{q}$ is amount of metal adsorbed per unit mass of adsorbent $(\mathrm{mg} / \mathrm{g})$ at equilibrium time, $\mathrm{V}$ is the volume of metal solution $(\mathrm{ml}), \mathrm{W}$ is mass of adsorbent $(\mathrm{g}), \mathrm{C}_{\mathrm{i}}$ and $\mathrm{C}_{\mathrm{e}}$ are concentration of metal ions at initial and at equilibrium time respectively.

\section{Results and Discussion}

\section{Characterization}

The morphological difference of the surface of the TL and ATL are visually shown in Fig. 1. The surface of adsorbent became much rougher after amination which confirmed the chemical modification of 
the sorbent. The surface of aminated biosorbent is full of cavities which are expected to enhance the metal binding capacity of the adsorbent.

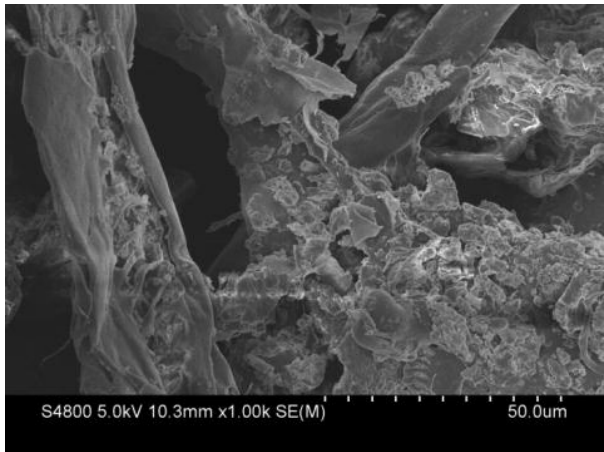

1 a

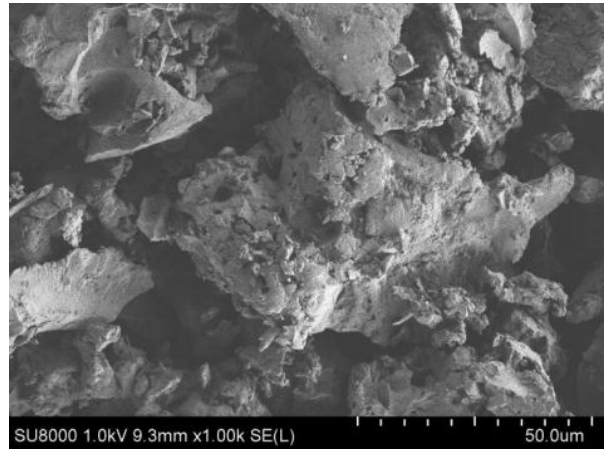

$1 \mathrm{~b}$

Figure 1: Scanning Electron Microscopic images of (a) TL and (b) ATL

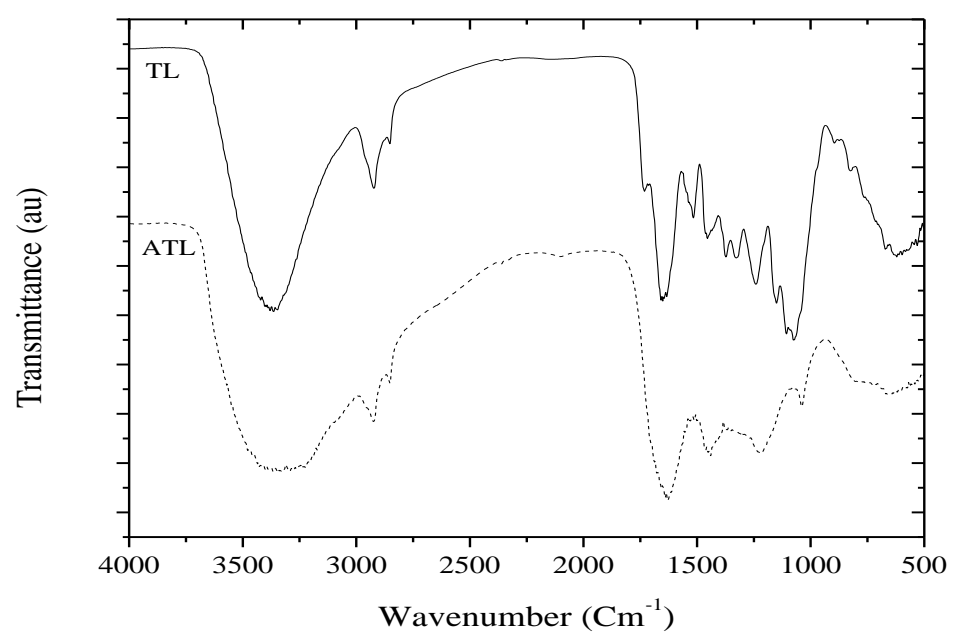

Figure 2: Fourier Transform Infrared spectra of TL and ATL

The FTIR-spectra of TL and ATL are shown in Fig. 2. In the spectrum of TL the broad and intense peak around $3380 \mathrm{~cm}^{-1}$ corresponds to the $\mathrm{O}-\mathrm{H}$ stretching vibration. It indicates the free $\mathrm{OH}$-group of alcohols and polyphenols present in cellulose and lignin. The C-H stretching peak is observed at $2923 \mathrm{~cm}^{-}$ ${ }^{1}$ and the peak at $1647 \mathrm{~cm}^{-1}$ is due to $\mathrm{C}=\mathrm{O}$ group. After chemical modification the spectrum of ATL shows many significant changes. In the spectrum of ATL, the strong broad band ranging from about 3085 $\mathrm{cm}^{-1}$ to $3653 \mathrm{~cm}^{-1}$ corresponds to the combination of stretching vibration bands of $\mathrm{OH}$ and $\mathrm{NH}$ groups. Similarly the peaks at $1433 \mathrm{~cm}^{-1}$ and $1094 \mathrm{~cm}^{-1}$ correspond to $\mathrm{CH}$ bending and $\mathrm{CN}$ stretching vibration respectively ${ }^{13}$. The information obtained from FTIR, indicates the introduction of amino group on the surface of the adsorbent. 


\section{Effect of $p H$}

The metal adsorption is dependent on the $\mathrm{pH}$ of the solution, as it affects the surface charge of adsorbent, the degree of ionization and the species of adsorbate. The adsorption increases with increase of $\mathrm{pH} 1$ ti $\mathrm{pH} 6$ as shown in Fig. 3. At low pH metal ions compete with $\mathrm{H}+$ ions for binding sites. As $\mathrm{pH}$ increases concentration of $\mathrm{H}+$ ions decrease and positive charge density on the sorption sites also reduced which enhances the adsorption of metal ions to get optimum value. At still higher $\mathrm{pH}$, precipitation occurs.

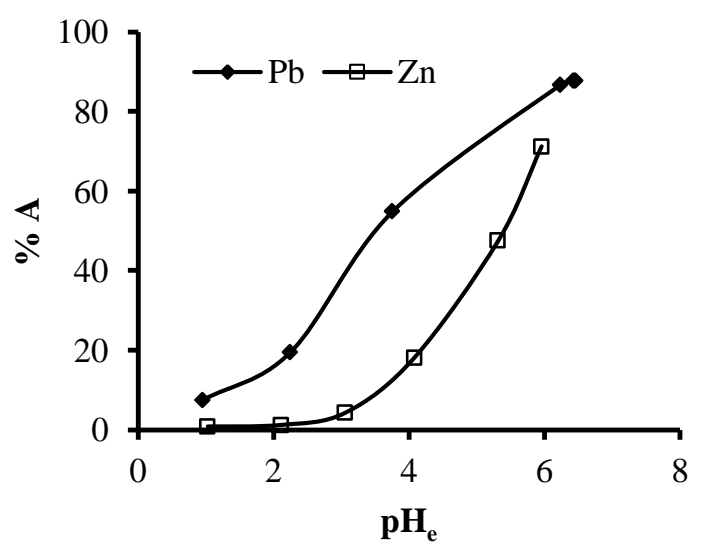

Figure 3: Effect of $\mathrm{pH}$ on the adsorption of $\mathrm{Pb}^{++}$and $\mathrm{Zn}^{++}$onto ATL

\section{Effect of contact time}

Adsorption experiments were carried out for different times with a fixed concentration of metal ions $(50 \mathrm{mg} / \mathrm{L})$ and adsorbent dose of $25 \mathrm{mg}$ at optimum $\mathrm{pH}$. The results are presented in Fig. 4. The equilibrium is reached within 150-160 minutes and reached a saturation level. In the initial state the adsorbed ions occupy selectively on the active sites on the adsorbent. As the contact time increases the active sites on the adsorbent are filled. The rate of adsorption gradually become slower and reached a plateau.

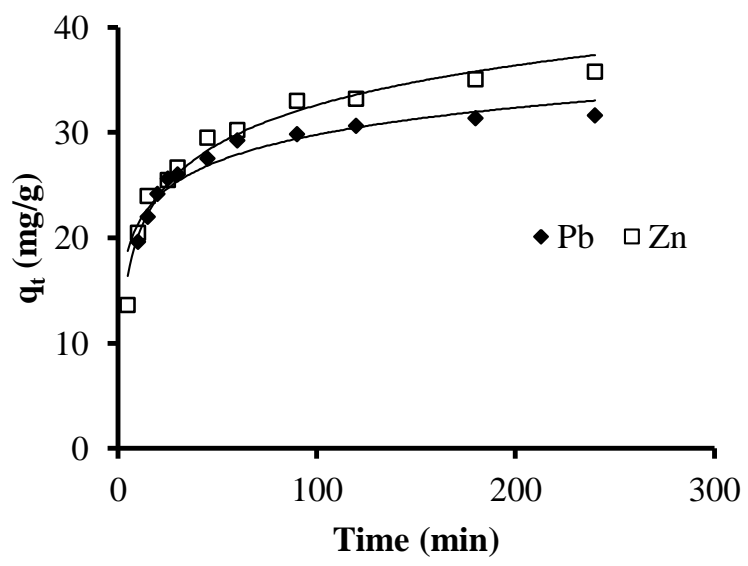

Figure 4: Adsorption kinetics of $\mathrm{Pb}^{++}$and $\mathrm{Zn}^{++}$onto ATL 


\section{Effect of initial concentration}

The effect of initial concentration in the removal of metal ions was studied at various concentrations of $25-800 \mathrm{mg} / \mathrm{L}$ of metal ions and $25 \mathrm{mg}$ of adsorbent at optimum $\mathrm{pH}$. The results shown in Fig. 5 indicate that the percentage removal of metal ions initially increases and the further increase in concentration decreases the percentage removal, indicating that the metal uptake is dependent on the initial concentration of metal ions in solution. At low concentration of metal ions, the ratio of number of moles of metal ions to the available surface area is low. Hence adsorption at low concentration of metal ions is independent of initial concentration of metal ions. At higher concentration, the available sites for adsorption are already saturated and metal removal is dependent on the initial concentration of metal ions $^{14}$.

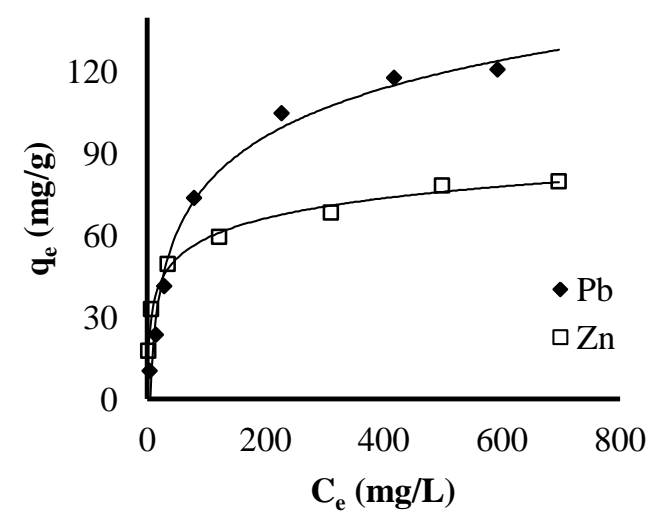

Figure 5: Adsorption isotherms for the adsorption of $\mathrm{Cu}^{++}$and $\mathrm{Zn}^{++}$onto ATL

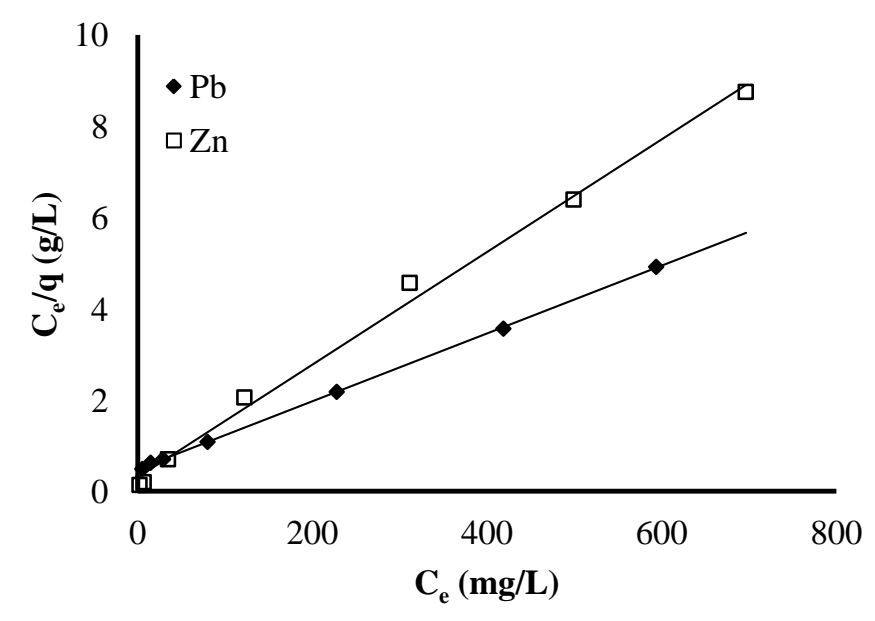

Figure 6: Langmuir plot for adsorption of $\mathrm{Pb}^{++}$and $\mathrm{Zn}^{++}$onto ATL

The isotherm curve suggested that the sorption is according to Langmuir adsorption model. The linear form of the Langmuir model was used as shown below 


$$
\frac{C_{\mathrm{e}}}{\mathrm{q}_{\mathrm{e}}}=\frac{1}{\mathrm{q}_{\mathrm{m}} \mathrm{b}}+\frac{\mathrm{C}_{\mathrm{e}}}{\mathrm{q}_{\mathrm{m}}}
$$

where, $\mathrm{C}_{\mathrm{e}}(\mathrm{mg} / \mathrm{g})$ is the concentration of metal ions after adsorption, $\mathrm{q}_{\mathrm{e}}(\mathrm{mg} / \mathrm{g})$ is the amount of metal ions adsorbed, $\mathrm{q}_{\mathrm{m}}(\mathrm{mg} / \mathrm{g})$ is the maximum adsorption capacity and $\mathrm{b}(\mathrm{L} / \mathrm{mg})$ is the binding constant. The linear plot of $\mathrm{C}_{\mathrm{e}} / \mathrm{q}_{\mathrm{e}}$ vs. $\mathrm{C}_{\mathrm{e}}$ (Fig. 6) indicated the applicability of adsorption isotherm. The value of $\mathrm{q}_{\max }$ $(\mathrm{mg} / \mathrm{g})$ and $\mathrm{b}(\mathrm{L} / \mathrm{mg})$ were calculated using the linear plot. The parameters of Langmuir isotherm for adsorption of $\mathrm{Pb}^{++}$and $\mathrm{Zn}^{++}$are shown in Table 1. The $\mathrm{q}_{\max }$ for the adsorption of $\mathrm{Pb}^{++}$and $\mathrm{Zn}^{++}$onto ATL are $120.8(\mathrm{mg} / \mathrm{g})$ and $79.76(\mathrm{mg} / \mathrm{g})$ respectively.

Table 1: Langmuir adsorption isotherm model parameters and experimental $q_{\max }$

\begin{tabular}{|c|c|c|c|c|}
\hline Metal ions & $\begin{array}{c}\mathrm{q}_{\max }(\mathrm{mg} / \mathrm{g}) \\
\text { Langmuir model }\end{array}$ & $\begin{array}{c}\mathrm{q}_{\max }(\mathrm{mg} / \mathrm{g}) \\
\text { Experimental }\end{array}$ & $\mathrm{b}(\mathrm{L} / \mathrm{mg})$ & $\mathrm{R}^{2}$ \\
\hline $\mathrm{Pb}^{++}$ & 120.8 & 142.85 & 0.014 & 0.999 \\
\hline $\mathrm{Zn}^{++}$ & 79.76 & 81.30 & 0.040 & 0.995 \\
\hline
\end{tabular}

\section{Adsorption Kinetics}

The kinetic data of adsorption of $\mathrm{Pb}^{++}$and $\mathrm{Zn}^{++}$onto ATL were analysed using linear form of pseudosecond order kinetic model ${ }^{15}$. The integrated form of the model is given in equation (4)

$$
\frac{t}{\mathrm{q}_{\mathrm{t}}}=\frac{1}{K_{2} q_{e}^{2}}+\frac{\mathrm{t}}{q_{e}}
$$

where $\mathrm{q}_{\mathrm{t}}(\mathrm{mg} / \mathrm{g})$ is the amount of metal ions adsorbed at time $\mathrm{t}(\mathrm{min}), \mathrm{K}_{2}(\mathrm{~g} / \mathrm{mg} / \mathrm{min})$ is the rate constant of pseudo-second order kinetic model ${ }^{15}$. Fig. 7 shows the kinetic plot for pseudo-second order reaction rate.

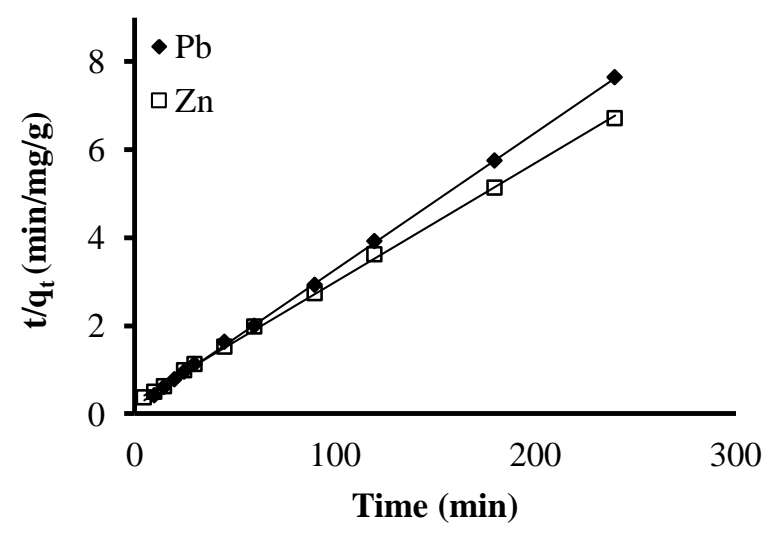

Figure 7: Pseudo- second order kinetic model for adsorption of $\mathrm{Pb}^{++}$and $\mathrm{Zn}^{++}$onto ATL 
The values of rate constant and correlation coefficients are given in Table 2, which indicates the applicability of pseudo-second order kinetics for adsorption of $\mathrm{Pb}^{++}$and $\mathrm{Zn}^{++}$onto ATL.

Table 2: Pseudo second order kinetics for $\mathrm{Pb}^{++}$and $\mathrm{Zn}^{++}$onto ATL

\begin{tabular}{|l|r|c|}
\hline Metal ions & $\mathrm{K}_{2}(\mathrm{~g} / \mathrm{mg} / \mathrm{min})$ & $\mathrm{R}^{2}$ \\
\hline $\mathrm{Pb}^{++}$ & 0.006121 & 0.999 \\
\hline $\mathrm{Zn}^{++}$ & 0.002499 & 0.999 \\
\hline
\end{tabular}

\section{Conclusion}

In this study exhausted tea leaves has been evaluated as an efficient bioadsorbent for removal of $\mathrm{Pb}^{++}$ and $\mathrm{Zn}^{++}$from their aqueous solutions. The adsorbent was aminated with hydrazine monohydrate and that aminated tea leaves was characterized by elemental analysis, SEM, FTIR. The adsorption capacity of the adsorbent was found to be increased with increasing $\mathrm{pH}$ upto optimum $\mathrm{pH}$ for metal ions. The equilibrium data fitted Langmuir isotherm with high coefficients which suggest that the adsorption process followed monolayer sorption. The kinetic study of the sorption process responds to pseudosecond order rate. Hence the aminated tea leaves can be used as an efficient and cost effective biosorbent for treatment of effluents containing the metal ions.

\section{References}

1. R. Ayyappan, A.C. Sophia, K. Swaminathan, S. Sandhya, Process Biochem., 2005, 40, 1293

2. B. Volesky, Z.R. Holan, Biotechnol. Prog., 1995, 11, 235

3. P. Miretzky, C. Munoz, A.C. Chavez, Bioresource Technol., 2008, 99, 1211

4. V.M. Nurchi, I. Villaescusa, Coodination Chemistry Reviews, 2008, 252, 1178

5. S. Babel, T.A. Kurniawan, J. Hazardous Materials, 2003, B97, 219

6. K.N. Ghimire, K. Inoue, K. Ohto, T. Hayasida, Biores. Technol., 2008, 99, 32

7. M.C. Basso, E.G. Cerrella, A.L. CuKierman, Ind. Eng. Chem. Res., 2002, 41, 3580

8. P.L. Homagai, K.N. Ghimire, K. Inoue, Separation Science and Technol., 2011, 46, 1

9. S. Chen, Q. Yue, B. Gao, X. Xu, J. Colloid and Interface Science, 2010, 349, 256

10. B.K. Biswas, K. Inoue, K.N. Ghimire, H. Harada, Bioresource Technol., 2008, 99, 8685

11. S. Deng, Y.P. Ting, Langmuir, 2005, 21, 5940

12. A.H. Mahvi, D. Naghipour, F. Vaezi, S. Nazmara, American J. Applied Sciences, 2005, 2(1), 372

13. R.L. Shriner, C.K.F. Hermann, T.C. Morill, D.Y. Curtin, R.C. Fuson, The Systematic Identification of Organic compounds, Seventh ed. Wiley, New York, 1998.

14. K.N. Ghimire, K. Inoue, K. Makino, T. Miyajima, Sep. Sci. Technol.,12 (2002), 37, 2785

15. Y.S. Ho, G. McKay, Process Biochemistry, 1999, 34, 451 